\title{
Effect of cement dust on soil physico-chemical properties around cement plants in Jaintia Hills, Meghalaya
}

\author{
R. Eugene Lamare ${ }^{1,2^{+}}$, O.P. Singh ${ }^{1}$ \\ ${ }^{1}$ Department of Environmental Studies, North-Eastern Hill University, Shillong-793022, Meghalaya, India \\ ${ }^{2}$ Department of Environment and Traditional Ecosystems, Martin Luther Christian University, Shillong 793006, Meghalaya, India
}

\begin{abstract}
Investigation was carried out to assess the effect of cement dust deposition on the physico-chemical properties of soil near some cement plants in Jaintia Hills, Meghalaya. Soil samples were collected and analysed and compared with the control site. Comparison of various soil physico-chemical parameters revealed that cement dust emanating from cement plants has changed the soil quality in the surrounding areas of cement plants. The normal soil $\mathrm{pH}$ in the area is generally acidic. However, due to the continuous deposition of cement dust soil pH was found slightly alkaline near the cement plants. The higher values of soil parameters such as electrical conductivity and bulk density were also noticed near the cement plants. However, lower values of water holding capacity, soil moisture content, soil organic carbon and total nitrogen content were found compared to the control sites. The effect of cement dust deposition on soil is more in areas nearer to the cement plants. At present the changes may not be so serious but if this trend continues, soil properties of a vast area around the cement plants are likely to change leading to multiple effects on flora, fauna and socio-economy of the area.
\end{abstract}

Keywords: Cement dust, Change in soil quality, Jaintia hills, Meghalaya

\section{Introduction}

Cement manufacturing industries are considered as one of the major environmental polluting industries in the world. It ranks 17 in the directory of polluting industries listed by Central Pollution Control Board, India. At the factory site, activities such as heating of the raw material like limestone, gypsum, red alluvium in the kiln and the burning of coal in the factory release particulate matter into the surrounding areas. Handling of cement also releases cement dust in the air. Thus, the particulates and dust released during various stages of cement manufacturing are likely to have adverse impact on different component of the environment such as air, water, soil and flora and fauna [1].

Cement dust is considered as one of the major pollutant emitted from cement manufacturing plants [2]. Dusts generated from the plants are easily transported and disperse by wind and are then deposited widely into the nearby areas. The long term depositions of dust impart pollution on soil, plants and water bodies due to its constant spreading and falling on the ground [3]. The soil quality is adversely affected by continuous depositions of cement dust and long term changes will subsequently have an adverse impact on the soil ecological communities and even might become unfavourable to plant growth $[4,5]$.

Cement dust are potentially harmful to the environment including soil. The cement dust has high calcium content in it; thus the dust tends to be highly alkaline in nature $[2,6]$. The dust generated from cement plants is composed of calcium silicate and calcium aluminate. When the dust is deposited on the soil surface, it along with soil forms cement like material which is hard and crystalline. Such material ultimately forms a layer of hard crust on soil surface [3]. This inevitably has an impact on the soil properties. The direct effects of the cement dust pollution are alkalization of the soil ecosystem and the alteration of its chemical composition. The dust particles can enter the soil as dry, humid or occult deposits and then undermine its physico-chemical properties [7]. Similar studies that emphasised on adverse impact of cement dust pollution on soil quality have also been reported in Saudi Arabia [8], Iran [9] and Jamaica [10].

The Jaintia Hills region is one of the three hill regions of the state of Meghalaya, India. A large number of cement plants have
This is an Open Access article distributed under the terms of the Creative Commons Attribution Non-Commercial License (http://creativecommons.org/licenses/by-nc/3.0/) which permits unrestricted non-commercial use, distribution, and reproduction in any medium, provided the original work is properly cited.
Received March 13, 2019 Accepted June 5, 2019

${ }^{\dagger}$ Corresponding author

Email: eugenelmr@gmail.com

Tel: +91-986-320-8851

Copyright (C) 2020 Korean Society of Environmental Engineers 
been established in Jaintia Hills for manufacturing of cement from locally available limestone. Some of these plants are operating for more than $15 \mathrm{y}$ and have contributed significant amount of cement dust in the surrounding areas. Although, studies on impact of limestone mining on water and soil have been done [11-15], no information is available on the effect of cement dust on soil in and around the cement plants of Jaintia Hills, Meghalaya. The present study reports the changes in soil quality due to deposition of cement dust operating in Jaintia Hills.

\section{Materials and Methods}

\subsection{Study Area}

The study was conducted in Jaintia Hills district of Meghalaya, India. The area has the maximum limestone deposits in the state of Meghalaya followed by Khasi Hills and Garo Hills. Extensive exploitation of limestone in the area started in 2004 after establishment of several cement manufacturing plants. At present, there are eleven cement plants already established. Currently, these are predominantly the major consumers of limestone resource in Meghalaya. All these cement plants were found to be located within an area of less than $10 \mathrm{~km}$ radius. The location of the study area is shown in Fig 1.

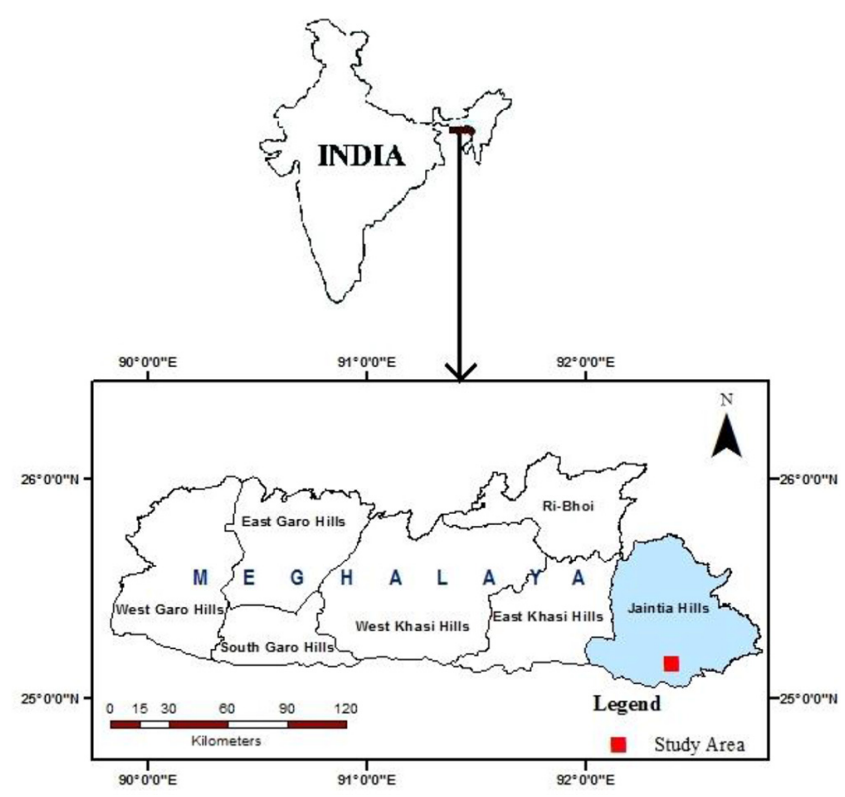

Fig. 1. Location map of the study area in Jaintia Hills Meghalaya.

\subsubsection{Geology}

The Jaintia Hills area is part of Meghalaya plateau which comprises of five different rock units namely: Pre-Cambrian gneissic complex with acid and basic intrusive, Shillong Group of rocks, Lower Gondwana rocks, Sylhet Traps and Cretaceous-Tertiary sedimentary rocks. Limestone is distributed predominantly in the southern fringe of Meghalaya plateau and falls under the rock formation units of Cretaceous-Tertiary sedimentary rock, which is then, div- ided into three groups i.e. the Khasi group, the Jaintia Group and the Garo group. The Jaintia Group is further divided into three formations which include the Longpar (lower), the Shella (middle) and the Kopili (upper) formations. The Shella formation is further subdivided into six members: the upper Sylhet Limestone (Prang limestone), upper Sylhet sandstone (Narpuh Sandstone), middle Sylhet Limestone (Umlatdoh limestone), middle Sylhet sandstone (Lakadong sandstone), lower Sylhet Limestone (Lakadong limestone) and lower Sylhet sandstone. The limestone deposited in Jaintia Hills possesses all the above three members of Sylhet limestone with alternating bands of limestone and sandstone. Thus, the limestone rocks found in Meghalaya belong to the Shella formations of the Jaintia Group of Cretaceous-Tertiary sedimentary rocks of Eocene geological age [16, 17].

\subsubsection{Soil}

In Jaintia Hills, the major types of soil found are loamy soil, lateritic soil and alluvial soil. The texture of soil varies from sandy to clayey loam. In general, the soils of Meghalaya are acidic in nature, rich in organic carbon, low in phosphorus with available potassium ranging between low to medium [18, 19]. The acidity of soil is due to presence of low concentration of pyrite which on oxidation forms sulphuric acid and makes the soil acidic.

\subsubsection{Climate}

The climate of the study area is greatly influence by the Southwest Monsoon originating from Bay of Bengal. Altitudinal variation is the main reason for the area to experience temperate humid climate and tropical to sub-tropical humid climatic conditions. The elevation of the area varies from $498 \mathrm{~m}$ to $630 \mathrm{~m}$ above M.S.L. The average annual rainfall recorded in Jaintia Hills was $4,173 \mathrm{~mm}$ [18]. The mean annual temperature recorded in the area is $23.6^{\circ} \mathrm{C}$ with minimum and maximum $14^{\circ} \mathrm{C}$ and $35.0^{\circ} \mathrm{C}$, respectively [20].

\subsection{Sampling}

Keeping in view the altitudinal variations and feasibility of collection of samples, soil sampling was carried at different locations from the two randomly selected cement plants, at a distance of $200 \mathrm{~m}, 400 \mathrm{~m}$ and $600 \mathrm{~m}$. The soil samples collected from a distance of about 4-5 km and 10-11 km away from selected cement plant-1 and 2, respectively were considered as control (SR). Long distance sampling was not possible due to the inaccessible topography of the area. The details of sampling sites near cement plants were displayed in Table 1. Sampling was done in winter, pre monsoon and post monsoon seasons of 2013. Soil samples were collected randomly from a depth of $0-20 \mathrm{~cm}$. From each location, the bulk samples collected were passed through a $2 \mathrm{~mm}$ sieve to remove rocks and pebbles. The soils were then properly mixed by stirring with hands on a clean polythene sheet and ultimately a composite soil sample was prepared following coning and quartering method. Samples were packed in air tight polythene bags and then transported to the laboratory. The collected samples were air dried, grinded and then passed through the $0.2 \mathrm{~cm}$ sieve for further analysis of various physical and chemical parameters.

\subsection{Analysis}

Soil $\mathrm{pH}$ and electrical conductivity were determined in a soil and 
Table 1. Soil Sampling Sites Near Cement Plants in Jaintia Hills Districts, Meghalaya

\begin{tabular}{|c|c|c|c|c|c|}
\hline Sl. No & Location & Code & Distance (m) & $\begin{array}{l}\text { Latitude } \\
\text { Longitude }\end{array}$ & Elevation (m) \\
\hline 1 & Undisturbed & SR & Reference / Control & $\begin{array}{lll}25^{\circ} & 16^{\prime} 36.98^{\prime \prime} & \mathrm{N} \\
92^{\circ} & 22^{\prime} 45.22^{\prime \prime} & \mathrm{E}\end{array}$ & 792 \\
\hline \multirow{3}{*}{2} & \multirow{3}{*}{ Site 1} & SC1_R1 & 200 & $\begin{array}{c}25^{\circ} 13^{\prime} 41.40^{\prime \prime} \mathrm{N} \\
92^{\circ} 23^{\prime} 2.76^{\prime \prime} \mathrm{E}\end{array}$ & 764 \\
\hline & & SC1_R2 & 400 & $\begin{array}{c}25^{\circ} 13^{\prime} 46.57^{\prime \prime} \mathrm{N} \\
92^{\circ} 23^{\prime} 6.05^{\prime \prime} \mathrm{E}\end{array}$ & 699 \\
\hline & & SC1_R3 & 600 & $\begin{array}{ll}25^{\circ} & 13^{\prime} 49.26^{\prime \prime} \mathrm{N} \\
92^{\circ} & 23^{\prime} 10.76^{\prime \prime} \mathrm{E}\end{array}$ & 636 \\
\hline \multirow{3}{*}{3} & \multirow{3}{*}{ Site 2} & SC2_R1 & 200 & $\begin{array}{cc}25^{\circ} & 12^{\prime} 2.66^{\prime \prime} \mathrm{N} \\
92^{\circ} & 22^{\prime} 51.19^{\prime \prime} \mathrm{E}\end{array}$ & 708 \\
\hline & & SC2_R2 & 400 & $\begin{array}{ll}25^{\circ} & 11^{\prime} 58.89^{\prime \prime} \mathrm{N} \\
92^{\circ} & 22^{\prime} 53.28^{\prime \prime} \mathrm{E}\end{array}$ & 681 \\
\hline & & SC2_R3 & 600 & $\begin{array}{lll}25^{\circ} & 11^{\prime} 42.82^{\prime \prime} \mathrm{N} \\
92^{\circ} & 22^{\prime} 57.66^{\prime \prime} \mathrm{E}\end{array}$ & 668 \\
\hline
\end{tabular}

NB: (SR - Soil from Control Site; SC1- Soil from cement plant site -1; SC2- Soil from cement plant site - 2).

distilled water suspension (1:2.5) using Deluxe pH-101 meter and Conductivity-601 meter, respectively. Parameters like moisture content, bulk density and water holding capacity (WHC) were estimated following gravimetric, laboratory and Keen Box-method, respectively [21, 22]. Walkley and Black rapid titration method was adopted for analysis of organic carbon in soil. Estimation of Total Nitrogen in soil was done following Kjeldahl method using Pelican Kelplus Model: Classic DX (VA). Molybdenum blue method was adopted for determination of available phosphorus (AP) using Systronics UV-VIS Spectrophometer-118 [23]. 1N ammonium acetate extract solution was used for estimation of available potassium using Microprocessor Flame Photometer Model 1381. The three way analysis of variance (ANOVA, $p<0.05$ ) was performed to determine whether there is any statistical significant differences or not between the means of different sites, seasons and years. Further, Dunnette's Multiple Comparison test was performed to find whether the sites at different distances affected with cement dust differ significantly or not from the control site (SR) at $p<0.05$.

\section{Results and Discussion}

Field observation revealed that the vegetation of the surrounding areas of cement plants was covered with cement dust. During post-monsoon and winter seasons the cement dust deposition is more severe in absence of rain. This has adversely affected the growth plants in the area. Many sensitive species might have reduced in their population and abundance. Plants and leaves fully covered by cement dust are shown in Fig 2. The deposition of cement dust has also affected the soil of the area as the clumping of soil particles on mixing with cement dust and forming hard crust can be seen in the area. The soil forming hard crust after mixing with cement dust can be seen in photographs of Fig 3.

The results of analysis various physico-chemical parameters of soil are summarized in Table 2 and represented graphically in Fig 4. The findings pertaining to various soil quality parameters are described and discussed in following sections.

\subsection{Soil Texture}

The texture of soil at all the sites was loamy sand in nature except at SC2_R1. The loamy sand characteristic of soil is generally due to natural geological features of the area itself. However, sandy texture at SC2_R1 could probably be due to the removal of vegetation cover in and around the area, contamination of sand, fine pieces of rocks from the creation of open space for storage of extracted limestone rocks and unpaved road used for transportations and parking spaces. Similar studies has been was reported with soils around the cement factory in Saudi Arabia having sandy loam to loamy sand [8]; sandy loam to loamy sand in North Ethiopia [24]; and sandy soils in Poland [25].

\subsection{Bulk Density}

The values of bulk density was found to vary from $1.38 \mathrm{~g} / \mathrm{mL}$ to $1.49 \mathrm{~g} / \mathrm{mL}$ at SC1_R1; $1.26 \mathrm{~g} / \mathrm{mL}$ to $1.38 \mathrm{~g} / \mathrm{mL}$ at SC1_R2 and $1.19 \mathrm{~g} / \mathrm{mL}$ to $1.33 \mathrm{~g} / \mathrm{ml}$ at SC1_R3. The values of bulk density at was found to varied from $1.42 \mathrm{~g} / \mathrm{mL}$ to $1.55 \mathrm{~g} / \mathrm{mL} ; 1.25 \mathrm{~g} / \mathrm{mL}$ to $1.29 \mathrm{~g} / \mathrm{mL}$ and $1.14 \mathrm{~g} / \mathrm{mL}$ to $1.33 \mathrm{~g} / \mathrm{mL}$ at SC2R1, SC2_R2 and SC2_R3, respectively. The results showed that BD in soils gradually decreases with increasing distance from the cement plants except during winter season at Site 2. The highest and lowest values of bulk density at both sites were observed in soil samples collected closest to and farthest from the cement factory, respectively. Throughout the study period, lowest bulk density was found in soil at SR. Soil near the cement plants tends to have higher values of bulk density due to low organic matter content in the soil [26]. Another finding reported that the marginal decrease in bulk density near the cement plants could be attributed to the change in percentage of sand, clay and content of organic matter in soil [27]. 

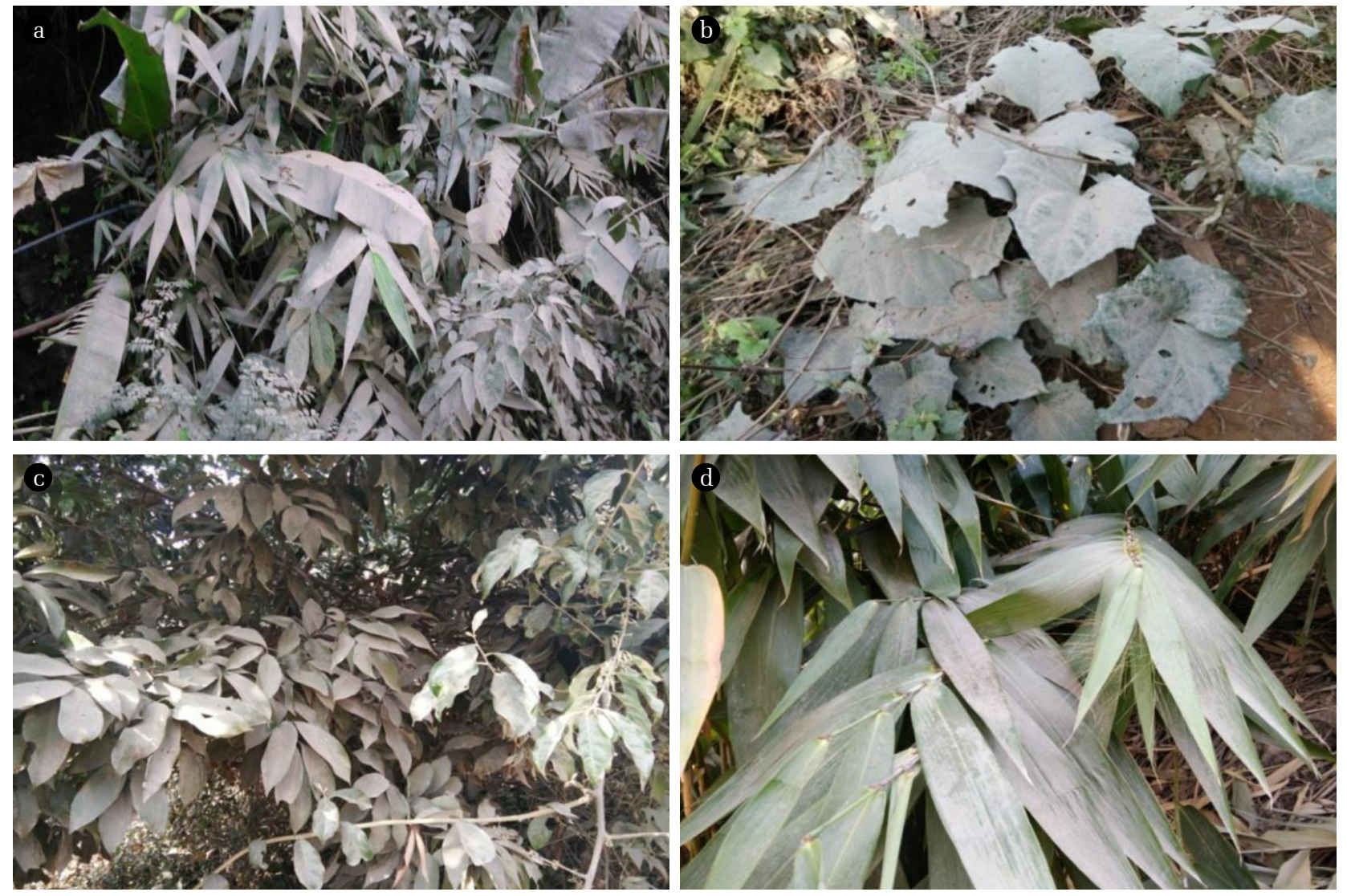

Fig. 2. Photographs showing plants fully covered with cement dust.

\subsection{WHC}

The percentage of WHC at Site 1 varied from $35.23 \%$ to $43.25 \%$ at $\mathrm{SC} 1 / 1 ; 41.75 \%$ to $45.06 \%$ at $\mathrm{SC} 1 / 2$; and $44.05 \%$ to $48.52 \%$ at SC1/3. Its value at SC2/1, SC2/2 and SC2/3 located near Cement Plant-2 were $31.89 \%$ to $33.71 \%$; $40.96 \%$ to $47.16 \%$; and $44.39 \%$ to $56.73 \%$, respectively. Throughout the study period different distances from the cement plants varie, WHC of soils from SR was found relatively high and varied from $50.04 \%$ to $60.30 \%$. The highest percentage recorded was during pre-monsoon season and lowest during winter season. However, soils collected at different distances from the cement plants varied from $35.23 \%$ to $48.52 \%$. Based on the results, WHC was found to increase significantly as we move away from the cement plants. The percentage of WHC was found lowest and highest at SC1_R1 and SC2_R1 and at SC1_R3 and SC2_R3, respectively. Soil at the contamination receiving sites particularly adjacent to cement factory retain least amount of water as compared to the soils at SR which bear maximum WHC [28]. Similarly, other findings also found that WHC of soils near cement plants in Himachal Pradesh decrease with increasing distance [26].

\subsection{Soil Moisture Content (SMC)}

SMC was found highest in soils collected from the SR when compared to soil samples collected from the vicinity of cement plants. The SMC values recorded at SR (control) site were found varying between $18.51 \%$ and $32.49 \%$. The amount of moisture present

around Site 1 was $9.79 \%$ to $16.96 \%$ at SC1_R1; $11.38 \%$ to $17.85 \%$ at SC1_R2 and $18.49 \%$ to $22.21 \%$ at SC1_R3. Similarly, amount of moisture present content at SC2_R1, SC2_R2 and SC2_R3 located around Site 2 were $2.55 \%$ to $10.69 \% ; 7.05 \%$ to $21.32 \%$ and $7.14 \%$ to $27.64 \%$, respectively. It was found that lowest SMC recorded was during winter and maximum during pre-monsoon season in most cases. The SMC was found to increase in its content with increasing distance from the cement plants. This indicates that soils at sites near the cement plants possessed low SMC whereas sites away possessed higher SMC in soil. The area away from the cement plants possesses good cover of vegetation. Thus, the fairly good SMC at these sites is attributed chiefly to presence of vegetation. However, minimal content of moisture at SC2_R1 is due to sandy texture of soil and area being devoid of plant growth. Similar study also found that amount of moisture content in soils increased progressively as distance from the factory site increased [29].

\subsection{Soil pH}

Soil $\mathrm{pH}$ at the SR varied from 4.4 to 5.5 indicating strongly acidic soil in the area. However, in the vicinity of the cement plants $\mathrm{pH}$ varied from neutral to slightly alkaline near the cement plants and slightly acidic away from the factory. $\mathrm{pH}$ of soil around site 1 was found to range from 6.7 to7.2 at SC1_R1; 6.1 to 6.8 at SC1_R2; and 5.8 to 6.5 at SC1_R3. Its values at SC2_R1, SC2_R2 and SC2_R3 

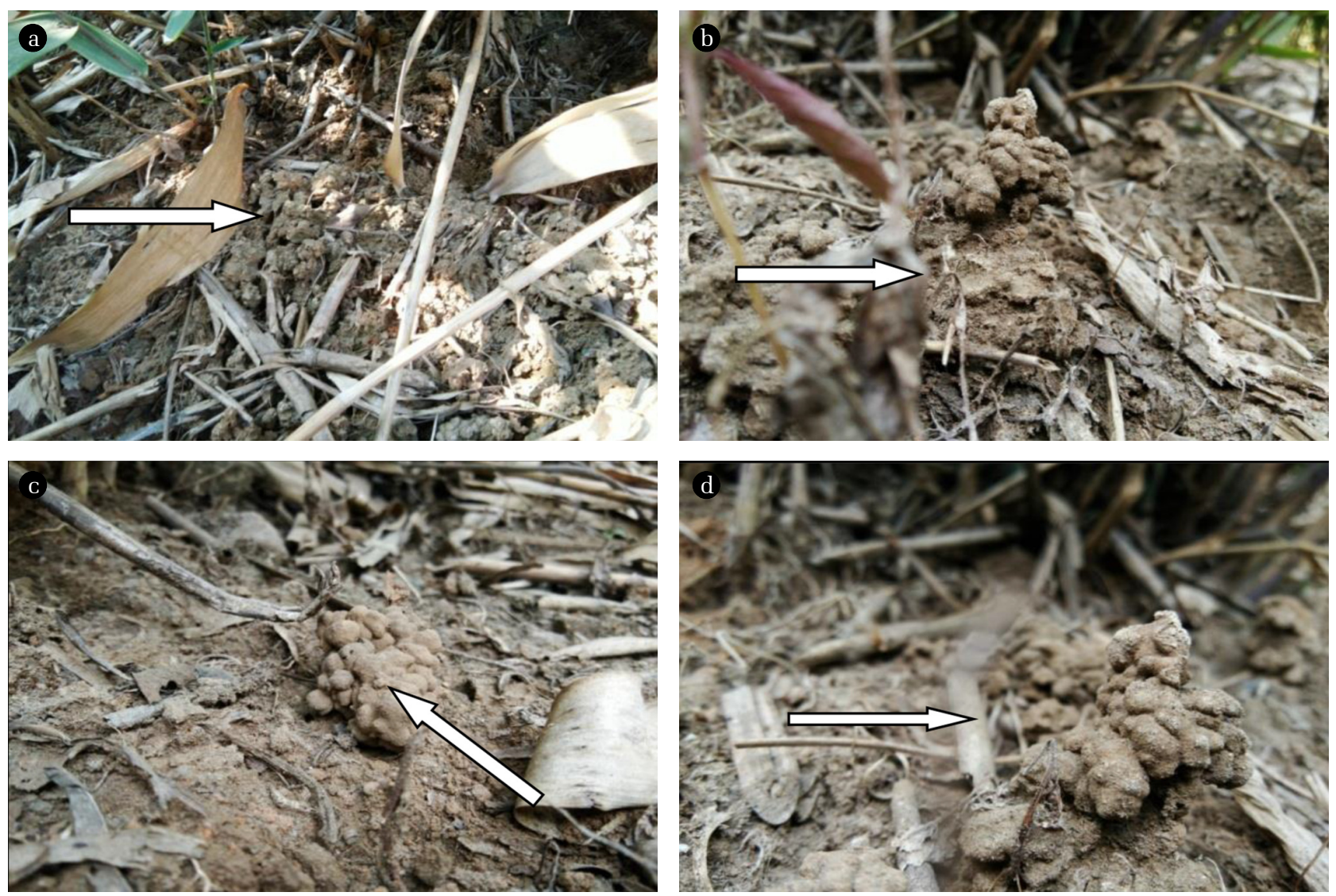

Fig. 3. Photographs showing soil forming hard crust after mixing with cement dust.

located around Site 2 varied from 7.5 to $7.9 ; 6.9$ to 7.3 and 5.5 to 6.6 , respectively. It was observed that $\mathrm{pH}$ value of the soil was recorded highest at site closest to the cement plant i.e. at SC1_R1 and SC2_R1 and lowest at SC1_R3 and SC2_R3 indicating decrease in soil $\overline{\mathrm{pH}}$ with increasing distance from the cement plants.

In general $\mathrm{pH}$ of soil in the area is acidic. However, due to deposition of cement dust on the soil near the cement plants, this caused a change in soil $\mathrm{pH}$ to the alkaline side. This change is probably due to liming effect of the dust [30]. Cement dust contains $\mathrm{CaCO}_{3}$, resulting in alkalinity when it comes in contact with soil $[31,6]$. Cement dust released from the industry when comes in contact with soil has indirect effect on soil quality [32, 33]. Another finding also confirmed that soil surrounding the cement plants was alkaline in nature, this is chiefly due to the influence of cement dust [34]. [35] and [36] also reported that soil $\mathrm{pH}$ varied from 7.06 to to 8.8 near the cement plants. In addition, the gradual decrease in soil $\mathrm{pH}$ with increasing distance from the cement plants was also reported [37, 3].

\subsection{Soil Electrical Conductivity (SEC)}

The comparison of SEC levels at SR with that of soils collected from varying distances around Site 1 and Site 2 showed that level of SEC decreases with increasing distances from the factory. The lowest SEC recorded was observed at SR which is located farthest from the cement plants. However, the highest level of SEC was observed in soil nearest to the factory site. Seasonally, the level of SEC was highest during winter seasons and lowest in post-monsoon season. The lesser levels of SEC during pre-monsoon and post-monsoon seasons may be chiefly due to the wash off of the cement dusts deposited on the top soil layer by rainfall.

The lowest SEC recorded was at SR and it varied from 0.028 $\mathrm{dS} / \mathrm{m}$ to $0.031 \mathrm{dS} / \mathrm{m}$. However, its value around Site 1 varied from $0.022 \mathrm{dS} / \mathrm{m}$ to $0.041 \mathrm{dS} / \mathrm{m}$ at SC1_R1; $0.02 \mathrm{dS} / \mathrm{m}$ to $0.036 \mathrm{dS} / \mathrm{m}$ at SC1 R2; and $0.014 \mathrm{dS} / \mathrm{m}$ to $0.033 \mathrm{dS} / \mathrm{m}$ at SC1 R3. The recorded SEC values at SC2_R1, SC2_R2 and SC2_R3 located around Site 2 from $0.095 \mathrm{dS} / \mathrm{m}$ to $0.512 \overline{\mathrm{dS}} / \mathrm{m} ; 0.079 \mathrm{dS} / \mathrm{m}$ to $0.171 \mathrm{dS} / \mathrm{m} ; 0.035$ $\mathrm{dS} / \mathrm{m}$ to $0.097 \mathrm{dS} / \mathrm{m}$, respectively. The concentration of EC in soils near cement plants was higher as compared with that of the reference site. Overall, the level of SEC around Site 2 was found comparatively highest. This is due to the significant amount of cement dust added into the soil surface. Based on the results, level of soil conductivity was found to increase considerably under the influence of cement dust.

Variations of soil EC due to influence of cement dust was confirmed by [6]. Similar findings have also been reported by other researchers. Cement dust contaminated sites had significantly higher SEC than in the control soil [38]. Study also reported that EC in soil around cement plants in North Ethiopia varied from 0.047 $\mathrm{dS} / \mathrm{m}$ to $0.432 \mathrm{dS} / \mathrm{m}$ indicating saline nature of soil [24]. Similarly, the effect cement dust on soil health in Raipur district, Chhattisgarh 
Table 2. The Values of Various Physico-chemical Parameters of Soil Samples Collected from Control Site and Around the Cement Plants

\begin{tabular}{|c|c|c|c|c|c|c|c|c|}
\hline \multirow{2}{*}{ Parameter } & \multirow{2}{*}{ Seasons } & \multirow{2}{*}{$\begin{array}{c}\text { Control } \\
\text { SR }\end{array}$} & \multicolumn{3}{|c|}{ Site 1} & \multicolumn{3}{|c|}{ Site 2} \\
\hline & & & SC1-R1 & SC1-R2 & SC1-R3 & SC2-R1 & SC2-R2 & SC2-R3 \\
\hline \multirow{3}{*}{ SMC } & $\mathrm{VIN}$ & $18.51 \pm 1.08$ & $10.06 \pm 0.11$ & $11.38 \pm 0.55$ & $18.51 \pm 1.08$ & $2.55 \pm 0.57$ & $7.05 \pm 0.29$ & $7.14 \pm 0.13$ \\
\hline & PRM & $32.49 \pm 0.28$ & $16.96 \pm 0.15$ & $17.85 \pm 0.06$ & $18.49 \pm 0.18$ & $10.69 \pm 0.88$ & $21.32 \pm 0.38$ & $27.64 \pm 0.5$ \\
\hline & POM & $28.17 \pm 0.69$ & $9.79 \pm 0.11$ & $13.7 \pm 0.02$ & $22.21 \pm 0.74$ & $9.49 \pm 0.09$ & $17.89 \pm 0.15$ & $23.71 \pm 0.24$ \\
\hline \multirow{3}{*}{$\mathrm{pH}$} & VIN & $5.4 \pm 0.15$ & $7.2 \pm 0.20$ & $6.8 \pm 0.15$ & $6.5 \pm 0.10$ & $7.9 \pm 0.06$ & $7.0 \pm 0.12$ & $6.6 \pm 0.10$ \\
\hline & PRM & $5.5 \pm 0.12$ & $6.9 \pm 0.10$ & $6.6 \pm 0.15$ & $6.5 \pm 0.17$ & $7.6 \pm 0.12$ & $7.3 \pm 0.06$ & $6.1 \pm 0.12$ \\
\hline & POM & $4.4 \pm 0.06$ & $6.7 \pm 0.12$ & $6.1 \pm 0.06$ & $5.8 \pm 0.06$ & $7.5 \pm 0.06$ & $6.9 \pm 0.06$ & $5.5 \pm 0.06$ \\
\hline \multirow{3}{*}{ EC } & WIN & $0.029 \pm 0.001$ & $0.041 \pm 0.001$ & $0.036 \pm 0.001$ & $0.033 \pm 0.002$ & $0.512 \pm 0.004$ & $0.171 \pm 0.004$ & $0.097 \pm 0.008$ \\
\hline & PRM & $0.028 \pm 0.001$ & 0.036 & $0.033 \pm 0.003$ & $0.022 \pm 0.001$ & $0.267=$ & $0.145 \pm 0.002$ & 0.065 \\
\hline & POM & $0.031 \pm 0.002$ & $0.022 \pm 0.0008$ & $0.020 \pm 0.0005$ & $0.014 \pm 0.0004$ & $0.095 \pm 0.001$ & $0.079 \pm 0.0023$ & $0.035 \pm 0.0023$ \\
\hline \multirow{3}{*}{$\mathrm{BD}$} & WIN & $1.17 \pm 0.0057$ & $1.38 \pm 0.0156$ & $1.26 \pm 0.07$ & $1.20 \pm 0.0177$ & $1.55 \pm 0.17$ & $1.29 \pm 0.0046$ & $1.33 \pm 0.0002$ \\
\hline & PRM & $1.06 \pm 0.0054$ & $1.40 \pm 0.0092$ & $1.38 \pm 0.226$ & $1.33 \pm 0.0033$ & $1.52 \pm 0.372$ & $1.26 \pm 0.0207$ & $1.14 \pm 0.0019$ \\
\hline & POM & $1.15 \pm 0.0121$ & $1.49 \pm 0.0103$ & $1.34 \pm 0.0050$ & $1.19 \pm 0.0161$ & $1.42 \pm 0.0104$ & $1.25 \pm 0.0184$ & $1.19 \pm 0.0084$ \\
\hline \multirow{3}{*}{ WHC } & WIN & $50.04 \pm 0.290$ & $40.35 \pm 1.161$ & $45.06 \pm 1.697$ & $48.52 \pm 0.408$ & $33.71 \pm 1.980$ & $40.96 \pm 0.459$ & $44.39 \pm 0.447$ \\
\hline & PRM & $60.30 \pm 0.273$ & $43.25 \pm 1.824$ & $43.08 \pm 1.996$ & $44.05 \pm 1.095$ & $32.98 \pm 1.325$ & $47.16 \pm 0.487$ & $56.73 \pm 2.79$ \\
\hline & POM & $55.09 \pm 0.838$ & $35.23 \pm 0.850$ & $41.75 \pm 0.526$ & $48.27 \pm 1.82$ & $31.89 \pm 1.051$ & $46.25 \pm 1.234$ & $51.73 \pm 0.608$ \\
\hline \multirow{3}{*}{ OC } & WIN & $2.58 \pm 0.321$ & $2.01 \pm 0.034$ & $2.30 \pm 0.876$ & $2.55 \pm 0.121$ & $0.50 \pm 0.265$ & $1.64 \pm 0.266$ & $1.66 \pm 0.034$ \\
\hline & PRM & $2.59 \pm 0.034$ & $2.10 \pm 0.059$ & $2.20 \pm 0.631$ & $2.12 \pm 0.068$ & $0.57 \pm 0.044$ & $0.94 \pm 0.034$ & $2.02 \pm 0.034$ \\
\hline & POM & $2.51 \pm 0.090$ & $1.31 \pm 0.068$ & $1.33 \pm 0.090$ & $1.82 \pm 0.059$ & $0.51 \pm 0.034$ & $1.78 \pm 0.034$ & $2.39 \pm 0.068$ \\
\hline \multirow{3}{*}{ TKN } & WIN & $0.286 \pm 0.047$ & $0.187 \pm 0.008$ & $0.224 \pm 0.024$ & $0.252 \pm 0.014$ & $0.098 \pm 0.028$ & $0.191 \pm 0.008$ & $0.205 \pm 0.029$ \\
\hline & PRM & $0.369 \pm 0.019$ & $0.173 \pm 0.021$ & $0.168 \pm 0.014$ & $0.187 \pm 0.008$ & $0.103 \pm 0.008$ & $0.168 \pm 0.014$ & $0.243 \pm 0.008$ \\
\hline & POM & $0.321 \pm 0.023$ & $0.154 \pm 0.024$ & $0.173 \pm 0.021$ & $0.205 \pm 0.008$ & $0.079 \pm 0.016$ & $0.224 \pm 0.014$ & $0.285 \pm 0.021$ \\
\hline \multirow{3}{*}{$\mathrm{AP}$} & WIN & $2.075 \pm 0.158$ & $1.792 \pm 0.323$ & $1.644 \pm 0.169$ & $1.597 \pm 0.163$ & $2.111 \pm 0.075$ & $1.956 \pm 0.027$ & $1.828 \pm 0.15$ \\
\hline & PRM & $3.550 \pm 0.160$ & $2.789 \pm 0.378$ & $2.242 \pm 0.115$ & $3.100 \pm 0.777$ & $4.554 \pm 0.402$ & $4.128 \pm 0.403$ & $3.672 \pm 0.027$ \\
\hline & $\mathrm{POM}$ & $8.044 \pm 1.750$ & $8.144 \pm 2.261$ & $6.383 \pm 1.109$ & $5.611 \pm 3.213$ & $10.556 \pm 1.711$ & $7.633 \pm 0.863$ & $4.794 \pm 0.170$ \\
\hline \multirow{3}{*}{ SEK } & WIN & $0.422 \pm 0.031$ & $0.708 \pm 0.020$ & $0.667 \pm 0.034$ & $0.603 \pm 0.032$ & $0.442 \pm 0.035$ & $1.435 \pm 0.009$ & $0.812 \pm 0.008$ \\
\hline & PRM & $0.612 \pm 0.023$ & $0.668 \pm 0.028$ & $0.532 \pm 0.028$ & $0.423 \pm 0.029$ & $0.418 \pm 0.032$ & $0.955 \pm 0.02$ & $1.095 \pm 0.031$ \\
\hline & POM & $0.427 \pm 0.013$ & $0.352 \pm 0.003$ & $0.587 \pm 0.013$ & $0.412 \pm 0.006$ & $0.475 \pm 0.010$ & $1.235 \pm 0.035$ & $0.608 \pm 0.01$ \\
\hline
\end{tabular}

NB: WIN = winter; PRM = Pre Monsoon; POM = Post Monsoon

and found that SEC decreases with distance from the cement plant [39]. Another report was also confirmed that sites located nearest to the cement plants bear higher level of EC and lowest were observed at the SR [28].

\subsection{Soil Organic Carbon (SOC)}

Analytical results revealed that concentrations of SOC were found to gradually increase in percentage as distance from factory increases. Its concentration varied from $1.31 \%$ to $2.10 \% ; 1.33 \%$ to $2.30 \%$; and $1.82 \%$ to $2.55 \%$ at sampling site SC1_R1, SC1_R2 and SC1_R3, respectively. The amount of SOC at Site 1 was found to increase in its content with increasing distance from the factory in all seasons except during pre-monsoon. Whereas, the concentrations around Site 2 was found to vary from $0.50 \%$ to $0.57 \%$ at sampling site SC2_R1; $0.94 \%$ to $1.78 \%$ at SC2_R2; $1.66 \%$ to $2.39 \%$ at SC2 R3. At all sites, its content decrease significantly near the factory site and increases with increasing distance. On the contrary, the maximum content of SOC was found at the SR and its values varied from $2.51 \%$ to $2.59 \%$.

A similar finding in relation to SOC content around cement plant was also reported in Poland [20]. Cement dust is alkaline in nature and when it comes in contact with soil subsequently mediate both the synthesis and decomposition of soil organic matter [40]. Finding of the concluded that the concentration of SOC at contamination receiving sites particularly at sites nearest to the cement factory was always low [28]. In relation with distances, [39] found that SOC content in soil tends to increase with increasing distance from the factory site.

\subsection{Total Kjeldahl Nitrogen}

Concentration of total nitrogen in soil samples collected from SR was found highest in the range of $0.286 \%$ to $0.369 \%$. However, 
it concentration around Site 1 ranged from $0.154 \%$ to $0.187 \%$ at sampling site SC1_R1; $0.168 \%$ to $0.224 \%$ at SC1_R2; and $0.187 \%$ to $0.252 \%$ at SC1_R3. Concentration of total nitrogen was found to improve with increasing distance from the cement plants in all seasons except in pre-monsoon season. In Site 2, its values varied from $0.079 \%$ to $0.103 \%$ at SC2_R1; $0.168 \%$ to $0.224 \%$ at SC2_R2; and $0.205 \%$ to $0.285 \%$ at SC2_R3. In this site, the value of total nitrogen was also found to increase with increasing distance from the cement plant.

The concentration of nitrogen was also found increasing significantly with increasing distance from the factory [3, 39]. Soil around the cement plant was found to exhibit lower concentrations of total nitrogen when compared to those away from the factory site. Soil collected and analysed around Calabar Cement Company in Nigeria have low content of nitrogen with values ranging from 0.01 to $0.08 \%$ [41]. This decrease in content of nitrogen could be attributed to the burning of plant residues during farming operations or dry season, leaching, and the high rate of organic-matter

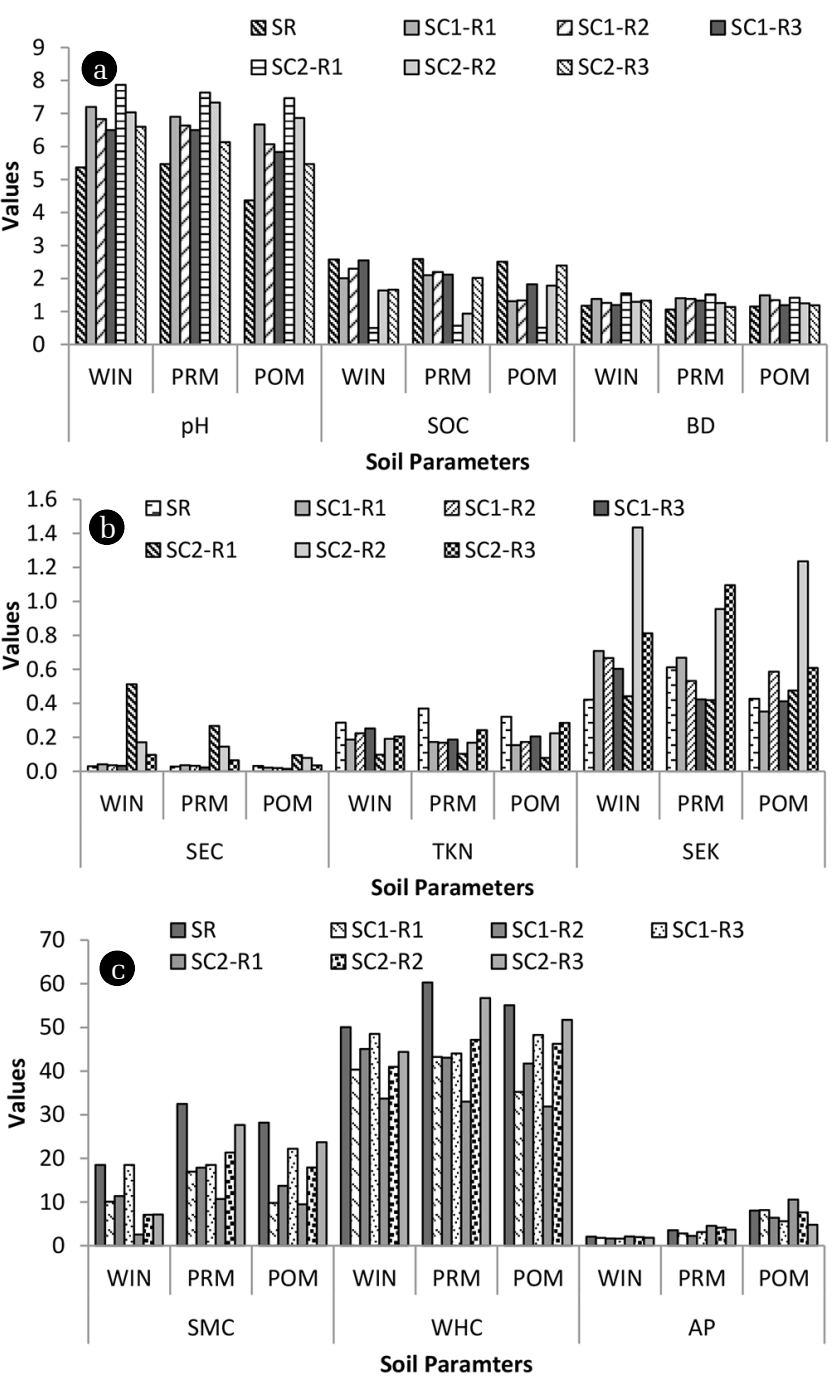

Fig. 4. Graphical representations of various soil physicochemical parameters collected from control (SR) and from sampling site 1 and 2. decomposition [42] as well as continuous cropping, which promotes rapid mineralization and absorption of nitrogen. The process of mineralisation of nitrogen decreases as nitrogen content increases [3].

\subsection{AP}

There is not much variation in AP content between the soils samples collected from SR and that from around the cement plants. However, the concentration of AP was found to decrease as distance from the factory site increases in all seasons except during pre-monsoon season at Site 1. The highest concentration of AP was recorded during post-monsoon season while the lowest was in winter season.

Phosphorus is one of the vital components of cement and it is deposited along with cement dust [43]. The availability of phosphorous in soil is heavily dependent upon the soil $\mathrm{pH}$ and its form present in the soil. Cement dusts contain calcium and when it comes in contact with phosphorus forms chelate resulting in reduction of phosphorus availability in the soils [3]. In addition, the lower level of AP could be due to phosphorus fixation into unavailable forms, such as calcium phosphates [44] which could be attributed to large quantities of calcium deposited in the highly dusted areas. In the same context, [39] also found that availability of phosphorous in soil is lowest near the cement plants and highest away from the cement plants.

\subsection{Soil Exchangeable Potassium (SEK)}

SEK at the SR and at around the cement plants showed not much variation seasonally. Its content at all sites varied from $0.352 \mathrm{mg} / \mathrm{g}$ to $1.435 \mathrm{mg} / \mathrm{g}$. It was observed that the concentration of potassium in soil gradually decrease with increasing distance from the factory in all seasons except during post-monsoon season at Site 1. However, maximum concentration throughout the study period was found at SC2_R2 at Site 2 in all seasons except during pre-monsoon season.

The concentration of SEK decreased with increasing distance from the factory. The higher concentration of SEK at sites located adjacent to the cement plants during winter season could be attributed to continuous deposition of cement dust in the soil. Cement dust tend to increase potassium content in soils [39]. The potassium content in soil near a cement factory in Madhya Pradesh was also found to increase significantly [3]. Similar findings were also reported by other researchers $[6,8,28,39]$. This increase is attributed to cement dust pollution. Similar finding reported that cement dust improved potassium content in soil and tend to remain higher than other cations [45].

\subsection{Statistical Analysis}

The analytical data of various soil physicochemical parameters were subjected to three way analysis of variance (ANOVA, p < 0.05) and Dunnette's test. The results revealed that data of different sites selected near Cement Plant-1 was found to vary significantly between different years, seasons and sites except for SMC and Soil pH (between years); BD and TP (between seasons) and AP between sites where $\mathrm{p}>0.05$. The Dunnette's test showed that data of these different sites near the cement plants differ significantly when compared with SR except for SEC (showing no significant difference between SC1-R2 with SR) and AP (no difference between 
all sites and SR). Data of soils near Cement Plant-2 was found to vary significantly between different years, seasons and sites except for SOC between years. The Dunnette's test here also revealed that significant difference exist between soil samples near the cement plants compared to those of SR except in respect of BD and $\mathrm{TP}$ at SC2-R3 and AP where no variations $(p>0.05)$ was found when compared with that from SR.

\section{Conclusions}

The results of various soil physico-chemical parameters analysed revealed that the soil samples from the SR possess better soil quality compared to that collected from different sites around the cement plants. The normal soil $\mathrm{pH}$ in the area is generally acidic. However, due to the continuous deposition of cement dust soil $\mathrm{pH}$ was found slightly alkaline near the cement plants. So, in respect of $\mathrm{pH}$, there is improvement in soil quality due to deposition of cement dust. The values of soil parameters such as WHC, soil moisture content, SOC and total nitrogen content were found to increase significantly with increasing distance from the factory sites whereas there was a decrease in $\mathrm{pH}$, electrical conductivity and bulk density values with increasing distance from the factory. The effect of dust deposition on soil is more in the areas nearer to the cement plants. Based on our findings, it can be concluded that if such trend of dust deposition continues, soil properties of a vast area around the cement plants are likely to change in terms of its physico-chemical properties. These changes will in turn have multiple deleterious effects particularly on agriculture, flora, fauna and socio-economy of the area in the near future.

\section{Acknowledgments}

The first author is thankful to the Ministry of Social Justice \& Empowerment and the Ministry of Tribal Affairs, (GoI), New Delhi for awarding Rajiv Gandhi National Fellowship for ST students. We would like to extent our sincere gratitude to the people of Nongsning, Mynkree, Wahiajer-Narpuh and Lumshnong village for their support and cooperation in this study.

This article was presented at the International Conference on Chemistry and Environmental Sustainability (ICCES-2018) held on 19-22 February 2019, Mizoram University, India.

\section{References}

1. Akeem AO. Impact of Ewekoro cement factory on the surrounding water resources [dissertation]. Abeokuta: Univ. of Agriculture, Abeokuta, Nigeria; 2008.

2. Zargari F, Hekmatshoar H, Dilmaghani A, Eslam BP. Chemical and physical properties of Soofian's cement dust and its effect on some aspects of growth in two cultivars of sunflower. J. Environ. Res. Dev. 2008;3:20-29.

3. Jain R, Jain PL. Pollution of soil due to cement factory near Narsingarh, Madhya Pradesh (India). J. Environ. Res. Dev. 2006;1:151-154.
4. Parthasarathy S, Arunachalam M, Natarajan N. Effect of cement dust pollution on certain physical parameter of maize crop and soils. Ind. J. Environ. Health 1975;17:114-120.

5. Mandre M, Ots K, Rauk J, Tuulmets L. Impacts of air pollution emitted from the cement industry on forest bioproduction. Oil Shale 1998;15:353-364.

6. Amos BB, Musa I, Abashiya M, Abaje IB. Impacts of cement dust emissions on soils within $10 \mathrm{~km}$ Radius in Ashaka Area, Gombe State, Nigeria. Environ. Poll. 2015;4:29-36.

7. Addo MA, Darko EO, Gordon C, et al. Evaluation of heavy metals contamination of soil and vegetation in the vicinity of a cement factory in the volta region, Ghana. Int. J. Sci. Technol. 2013;2:40-50.

8. Al-Omran AM, El-Maghraby SE, Nadeem MEA, El-Eter AM, Al-Qahta SMI. Impact of cement dust on some soil properties around the cement factory in al-hasa oasis, Saudi Arabia. Am.-Eurasian J. Agri. Environ. Sci. 2011;11:840-846.

9. Ghorbani H, Aghababaei A, Mirkarimi HR. The evaluation of industrial cement production plant on the environmental pollution using magnetic susceptibility technique. Agri. Sci. 2013;4:792-799.

10. Mandal A, Voutchkov M. Heavy metals in soils around the cement factory in Rockfort, Kingston, Jamaica. Int. J. Geosci. 2011;2:48-54.

11. Lamare RE, Singh OP. Degradation of water quality due to limestone mining in East Jaintia Hills, Meghalaya, India. Int. Res. J. Environ. Sci. 2014;3:13-20.

12. Lamare RE, Singh OP. Localised effect of artisanal and small scale mining of limestone mining on water quality in Meghalaya, India. Poll. Res. 2015;32:321-329.

13. Lamare RE, Singh OP. Application of CCME water quality index in evaluating the water quality status in limestone mining area of Meghalaya, India. The Ecoscan 2016;10:149-154.

14. Lamare RE, Singh OP. Limestone mining and its environmental implications in Meghalaya, India. ENVIS Bull. Himalayan Ecol. 2016;24:87-100.

15. Lamare RE, Singh OP. Changes in soil quality in Limestone mining area of Meghalaya, India. Nat. Environ. Poll. Technol. 2017;16:545-550.

16. Sarma K. Impact of coal mining on vegetation: Case study of Jaintia hills, district of Meghalaya, India [dissertation]. Enschede: International Institute for Geoinformation Science and Earth Observation; 2005.

17. Directorate of Mineral Resources (DMR) Profile. Government of Meghalaya, Shillong, Meghalaya; c2017 [cited 3 September 2017] Available from: http://megdmg.gov.in/.

18. Central Ground Water Board (CGWB), Ministry of Water Resources, Government of India. Ground Water Information Booklet, Jaintia Hills District, Meghalaya. North Eastern Region; 2012.

19. Megagriculture. Meghalaya Agriculture profile [Internet]. Available from: http://www.megagriculture.gov.in/.

20. CRIS. Customised rainfall information system from India meteorological department [Internet]. c 2017. Available from: http://hydro.imd.gov.in/hydrometweb/(ii2pr1mfd34ladq 52fmh3z45))/DistrictRaifall.aspx.

21. Maiti SK. Handbook methods in environmental studies. Vol. 
2: Air, Soil, and Overburden Analysis. Jaipur: ABD Publishers; 2003.

22. Gupta PK. Methods in environmental analysis water, soil and air. Jodhpur: Agrobios Publication; 2005.

23. Allen SE, Grimshaw HH, Parkinson JA, Christopher Q. Chemical analysis of ecological materials. Oxford: Blackwell Scientific Publications Oxford; 1974.

24. Estifanos S, Degefa A. Assessing the effect of cement dust emission on the physicochemical nature of soil around Messebo area, Tigray, North Ethiopia. Int. J. Ecol. Environ. Geol. 2012;3:12-20.

25. Dabkowska-Naskrêt H, Jaworska H, Dlugosz J. Assessment of the total nickel content and its available forms in the soils around cement plant Lafarge Poland. Int. J. Environ. Res. 2014;8:231-236.

26. Nisha R, Sagar A. Screening of indigenous cyanobacterial species from Darlaghat cement mining area of Himachal Pradesh. Int. J. Curr. Microbiol. Appl. Sci. 2016;5:50-58.

27. Guerrero C, Mataix-Solera J, Navarro-Pedreno J, Garcıa Orenes F, Gomez I. Different patterns of aggregate stability in burned and restored soils. Arid Land Res. Manage. 2001;15:163-171.

28. Magray RA. Studies on the impact of cement dust pollution on selected vegetable crop [Dissertation]. Kashmir: Univ. of Agricultural Sciences and Technology of Kashmir; 2012.

29. Stanley HO, Odu NN, Immanuel OM. Impact of cement dust pollution on physicochemical and microbiological properties of soil around Lafarge cement in South Western Nigeria. Int. J. Adv. Bio. Res. 2014;4:400-404.

30. Oludoye OO, Ogunyebi LA. Nutrients assessment of tropical soils around a mega cement factory in Southwest Nigeria. J. Ecol. Eng. 2017;18:21-28.

31. Swiercz A. Suitability of fine bark to evaluate pollution caused by cement-lime dust. J. For. Sci. 2006;52:93-98.

32. Vardaka E, Cook CM, Lanaras T, Sgardelis SP, Pantis JD. Effect of dust from a limestone quarry on the photosynthesis of Quercus coccifera, and evergreen sclerophyllous shrub. Bull. Environ. Conta. Toxicol. 1995;54:414-419.

33. Auerbach NA, Walker MD, Walker DA. Effects of roadside dis- turbance on substrate and vegetation properties in Arctic tundra. Ecol. Appl. 1997;7:218-235.

34. Shivkumar S, John DBA. Effect of cement pollution on soil fertility. J. Ecotoxicol. Environ. Mon. 2002;5:147-149.

35. Siddiqui NA, Kumar A, Selvan RT, Ziaiddin A. Assessment of soil quality near a cement industry. J. Ind. Poll. Cont. 2010;26:205-210.

36. Abdulrasoul MA, Salem EE, Mahmoud EAN, Ali ME, Salem MIA. Impact of cement dust on some soil properties around the cement factory in Al-Hasa Oasis, Saudi Arabia. Am.-Eurasian J. Agri. Environ. Sci. 2011;11:840-846.

37. Haynes BW, Kramer GW. Characterization of U.S. cements kiln dust. Washington D.C: U.S. Bureau of Mines, Department of the Interior. 1992.

38. Abdel-Rahman AM, Ibrahim MM. Effect of cement dust deposition on physiological behaviors of some halophytes in the salt marshes of Red Sea. Acad. J. Biol. Sci. 2012;3:1-11.

39. Khamparia A, Chattergee SK, Sharma GD. Assessment on effect of cement dust pollution on soil health. J. Environ. Res. Dev. 2012;7:368-374.

40. Rawat V, Katiyar R. A review: On the effects of cement dust on vegetation. Int. J. Sci. Inno. Res. Stud. 2015;3:39-45.

41. Ibanga IJ, Umoh NB, Iren OB. Effects of cement dust on soil chemical properties in the Calabar Environment, Southeastern Nigeria. Soil Sci. Plant Anal. 2008;39:551-558.

42. Periaswamy SP, Aduayi EA, Ashaye TI. Soil fertility of soils in Southeastern Nigeria. Nigerian J. Soil Sci. 1983;4:92-100.

43. Asubiojo OI, Aina PO, Oluwole AF, Arshed W, Akanle OA, Spyrou NM. Effect of cement production on the elemental composition of soils in the neighbourhood of the two cement factories. Air Water Soil Poll. 1991;57-58:819-824.

44. Brady NC, Weil RR. The nature and properties of soils. 12th ed. Prentice - Hall Inc. Simon and Schuster A. New Jersey: Viacon Company Upper Saddle River; 1999.

45. Seker C, Ozaytekin HH. Effect of portland cement on soil mechanical properties and seedling emergence of wheat in a silty loam soil. In: International Conference on Sustainability; 2002; Kenya. p. 274-281. 